\title{
STRATEGIC PLANNING OF SPORT TOURISM EVENTS ON DESTINATION BRANDS: EXAMINING THE ROLE OF HOME-GROWN SPORT
}

\author{
Janice HEMMONSBEY \\ University of Johannesburg, School of Tourism and Hospitality, \\ College of Business and Economics, South Africa, e-mail: janicehemmonsebey@yahoo.com
}

\section{Tembi M. TICHAAWA*}

University of Johannesburg, School of Tourism and Hospitality, College of Business and Economics, South Africa, e-mail: tembit@uj.ac.za

\begin{abstract}
Citation: Hemmonsbey, J. \& Tichaawa, T.M. (2019). STRATEGIC PLANNING OF SPORT TOURISM EVENTS ON DESTINATION BRANDS: EXAMINING THE ROLE OF HOMEGROWN SPORT. GeoJournal of Tourism and Geosites, 26(3), 794-807. https://doi.org/10.30892/gtg.26310-398
\end{abstract}

\begin{abstract}
This paper discusses the home-grown sport with a regular occurrence as equal opportunities for strategic planning. This study employed a qualitative research design which featured in-depth, semi-structured interviews with key industry stakeholders involved in sport event and tourism and destination branding organisations. A thematic analysis of the results revealed the imperative of events of the home-grown nature to contribute to the continued benefits relating to tourism and destination branding. The results further revealed the importance of including other tourism and destination branding offerings as part of the strategic planning and implementation of destination branding which consequently lengthen visitor stays. Moreover, stakeholders emphasised the importance of strategic planning through leveraging activities that underpin authentic destination brand awareness. The results of this paper add significant contributions to destination branding theory by investigating the role of sport for destination brand development. This paper further contributes to stakeholder policy and practice through its empirical findings that outline stakeholder views and strategies of planning home-grown events for brand-related benefits.
\end{abstract}

Key words: Strategic planning, home-grown events, sport tourism, South Africa, destination brand development

\section{INTRODUCTION}

Over the years, destination branding research has placed a particular focus on the role of branding in relation to the consumption of tourism destinations brands (Pike 2009; Jago et al., 2010; Chen \& Funk, 2010; Baker, 2012). Such studies have shown

\footnotetext{
* Corresponding author
} 
that the sport events industry is one of the biggest industries that serve as a catalyst for branding opportunities in which destinations can revel in the benefits of tourism. However, the globalisation of sport, together with the globalisation of mass media, has intensified the marketing pressures on tourism destinations to not only promote their brands through an association with sport, but has further advanced the competition among destinations to share in the domestic and international tourism markets that accompany sport events (Weed \& Bull, 2009; Gibson \& Lamont, 2018).

To withstand the advanced competition resulting from globalisation, destinations have become increasingly strategic in their approach to branding where they adopt particular tactics to gain a competitive advantage over other destinations.

Such tactics are generally linked to sport event leveraging through which stakeholders recognise events as opportunities to engage in strategic planning to achieve desired long-term impacts (Chalip, 2002). From a theoretical perspective, the current international literature discusses a number of cases where nations have successfully employed leveraging strategies towards achieving tourism destination brands through sport mega-events such as the Olympic Games and the Federation Internationalé de Football (FIFA) World Cup tournaments (Chalip, 2002; Chalip \& O'Brien, 2008; Grix, 2012; Karadakis \& Kaplanidou, 2012; Swart \& Bob, 2012; Knott, Fyall \& Jones, 2017; Tichaawa \& Bob, 2015; Ziakas, 2018). As a result of the global nature of sport mega-events in relation to participation, awareness, and media coverage, it is no surprise that such events provide significant opportunities for branding and or leveraging. Notwithstanding the opportunities that can be derived from mega-events, Chalip (2004), Ziakas (2018) and Ziakas and Costa (2011) strongly advocate the importance of an event portfolio consisting of home-grown, recurring events as part of the destination marketing strategy that will allow destinations to optimise the reach and frequency of target markets when leveraging home-grown events over the once-off mega-event. However, due to the scant theory to inform strategic planning of home-grown events that reinforce the associated branding opportunities, stakeholder effort to strategically plan around home-grown events to achieve brandrelated benefits might go unrealised and hence the focus of this current research.

Moreover, part of the sport event leveraging theory, according to Chalip (2004) and Hemmonsbey, Tichaawa and Knott (2018) illustrate the need for establishing strategic objectives which essentially aim to derive desired means for destination branding benefits. Even though these strategic objectives are realised in both developed and developing contexts, it still remains unclear how such objectives are incorporated in practice by developing nations where the priorities of such nations are skewed towards more pressing socio-economic issues (Hemmonsbey \& Knott, 2016; Hemmonsbey \& Tichaawa, 2019). In this paper, South Africa is used as a destination brand case study to provide insights into a developing destination context.

This was achieved by way of exploring the stakeholder views on the strategic planning of home-grown events to inform policy and practice. The article begins by offering an account of the destination branding discourse. This is followed by a contextualisation of sport tourism events by introducing home-grown events. Current debates around strategic planning through sport event leveraging are espoused.

Since South Africa is the chosen case study, we present an overview of the country as a sport destination. Findings from a series of interviews with various stakeholders to examine the main study objective are presented. We conclude that results and discussions of this paper revealed a significant contribution of home-grown sport events to establishing value propositions for destination brand positioning. 


\section{THE DESTINATION BRANDING DISCOURSE}

The concept of destination branding originated from the general branding literature and therefore has often been viewed as running parallel to the corporate, product and service branding theories (Balakrishnan, 2009). However, while it is on the premise of generic branding that destination branding is generally understood, destination branding often only indicates the modern form of tourism promotion (Anholt, 2005; Hanna \& Rowley, 2008; Boisen et al., 2018).

A widely recognised definition that builds on the premise of the generic branding theory towards the promotion of travel and tourism thus describe destination branding according to its unique and identifiable characteristics in its name, logo, and any other word or graphic; as well as the promise of delivering a memorable travel experience that is typically linked to unique associations of the destination (Ritchie \& Ritchie, 1998). More recent studies additionally argue that, destinations not only create memorable travel experiences for the benefit of unique associations, but they also seek to position their brands in such a way that the visitors' experiences of a destination will bring about repeat visits as well as create voluntary ambassadors for the destination (Morgan et al., 2010). For this reason, destinations increasingly view branding as a more strategic tool towards brand positioning (Filo etal., 2013).

Furthermore, Greaves and Skinner (2010) postulate that to develop a unique brand identity for tourism destinations will help the actual and potential tourists to differentiate a particular tourism destination from another destination. In line with this statement, Kapferer (2012) argues that it is of utmost importance for a place brand to possess a clear value proposition that constitutes the brand identity, so as to facilitate the derivation of the related benefits. Sport (events) are globally viewed as being powerful value propositions for positioning place brand identities, for the attaining of various branding benefits (Govers \& Go, 2009; Zhang \& Zhao, 2009; Hemmonsbey \& Knott, 2016). Melbourne, in Australia, remains one of the prime examples of a city that has positioned itself as one of the leading destination brands globally, due to its brand identity (logo), which showcases sport as one of its portfolios.

Elsewhere, the findings of Hemmonsbey and Knott (2016) reveal that Cape Town in South Africa has recently redeveloped its identity (in the form of its logo and slogan) with [sport] events being one of its investment and marketing strategies. These views and examples are consistent with Morgan et al. (2010) in that, tourism destinations should create a niche market and clearly distinguish a destination from other competing destinations in the face of globalisation. Such destinations can range from cities, towns, villages, nations (Camilleri, 2019). From the above discussion, it is clear that the wider context of destination branding extends towards brand differentiation applications to not only achieve brand awareness but also to achieve brand positioning.

Moreover, beyond just establishing a clear brand identity, destinations should look towards including a value proposition in the form of a special niche area which will subsequently benefit and sustain the tourism destination brand. For this paper, sport events will be explored as a tourism niche that are strategically planned and capitalised in order to derive tourism and destination branding outcomes.

\section{SPORT EVENTS AS A MEANS FOR STRATEGIC DESTINATION BRANDING}

The nature of sport events generally presents opportunities for host destinations to engage in branding practices which subsequently permit destinations to augment their brand awareness as well as communicate positive messages about the destination to the 
rest of the world. Likewise, opportunities for economic and social development are presented through sport event hosting. Further opportunities for strategic planning through stakeholder coordination of event leveraging are implied to achieve long-term destination branding benefits. As a consequence to their large-scale and international hosting nature, sport mega-events such as the Olympic Games and the FIFA World Cup have particularly proven to be an important feature in positioning nations to the international, or global, society (Horne \& Manzenreiter, 2006).

Mega-events have further proven to hold major legacy implications which can either be negative or positive, planned or unplanned, and tangible or intangible for the host and non-hosting community (Swart \& Bob, 2012; Nauright, 2013; Kim et al., 2015; Lui, 2016). Such legacies are associated with sporting, urban, infrastructural, economic, environmental, political and societal impacts (Cornelissen et al., 2011).

For example, the 2004 Olympic Games presented unique opportunities for Athens and Greece to diversify and enrich their destination's tourism product and their successful organisation of the Olympic Games has left valuable tangible and intangible legacies for Athens linked to its heritage and tourism infrastructure (Ziakas \& Boukas, 2014). Elsewhere, the 2008 Olympic Games brought a number of legacies to Beijing and the rest of China. These included social legacies comprising public health, education and volunteerism; and urban and environmental legacies involving its road and transportation infrastructure development, cultural/heritage preservation, environmental awareness, and venues/facilities upgrades (International Olympics Committee, 2009). Another example can be seen from the 2010 FIFA World Cup in South Africa, with an adoption of an African Legacy Programme with intent to maximise impacts of the World Cup for the broader African continent (Tichaawa \& Bob, 2015).

However, while the effects of sport on destinations are apparent in the legacy impacts after the staging of events, Tichaawa and Bob (2015) advocate that authorities must strategically plan for long-term impacts and not assume or anticipate such impacts to materialise. In the example of Athens, Ziakas and Boukas (2014) note that, despite of the success in organisation of the Olympic Games, there was an evident lack of coordination between commercial providers and public governing bodies towards a joint strategic approach to leverage the Games. For this reason, the aspiration to harness the post-Olympic facilities went unrealised. A forward-thinking theory is therefore presented by Chalip (2017), who suggests that the quality of impacts derived from sport mega-event hosting depends on a coordinated approach to event leveraging (which is discussed later in the paper). This advanced approach can either be a further challenge faced by host and non-host nations or, if effectively implemented, can maximise the potential for positive, long-term benefits (legacies), while minimising the potential risks to tourism and destination branding. Notwithstanding the abovementioned notions on the impact of mega-events towards destination branding, it is worth noting here that, there are limited mega-events that exist which leads to fierce competition among destinations in bidding to host such events.

Consequently, the degree to which the full extent of impacts are realised is limited to selected hosting nations. For this reason, the home-grown event is introduced to afford a wide-range of destinations with an equal opportunity for a share of the world's tourism market and subsequently derive its intended brand related benefits.

Hemmonsbey and Tichaawa (2018) describe home-grown events as recurring events that are smaller in size and scope compared to the mega-event but have a strong association with the destination's brand identity. Such events are further distinguished by their mass (local and international) participation and their innate characteristics in terms 
of their actual staging by using an outdoor, natural setting. Home-grown events are assumed to be conceptualised, produced, and nurtured by a particular locale. According to Brown, Chalip, Jago and Mules (2004) destinations strategically use events of this nature to strengthen its existing brand image as the associations of the event is consistent with one or more aspects of the destination. Therefore destinations benefit by choosing events that highlight for example, its beaches, landscape, or climate such as Cycle Tours, water sports, triathlons, and mountain bike races amongst other sports.

It is clear that events take various shapes and sizes and, depending on the destination aims, stakeholders may include either one or more type of events in their strategic planning to achieve tourism destination benefits. In fact, Chalip (2004), Ziakas and Costa (2011) and Ziakas (2018) encourage destinations to include an event portfolio consisting of more than one event in their strategic initiatives. In light of this view and in relation to the home-grown event theme, this study contextualises the home-grown event for destinations as part of their strategic planning and overall leveraging practices.

\section{STRATEGIC PLANNING THROUGH SPORT EVENTS LEVERAGING}

Essentially, strategic planning serves as the basis for leveraging in its approach to recognise events as an opportunity for designing and implementing strategies and tactics to achieve desired impacts. Earlier studies that delve in to the strategic planning of sport events argue the importance of assessing planned strategies pre-and post-event hosting (Cooper 1995; Bramwell, 1997). Advanced research on leveraging agrees with this view by referring to leveraging as a strategic ex-ante, analytical approach as opposed to an expost, impact-driven, outcomes approach (O'Brien \& Chalip, 2008; Smith 2014). Therefore, both planning techniques aim to produce 'forward thinking ... strategic approach', in terms of which both the impacts and the ways of achieving them are planned prior to an event (Smith, 2014). Also, strategic planning through leveraging advocates for the need to formulate strategic objectives that work towards an overall goal. Given the clear set of strategic objectives as a result of strategic planning, it is argued that stakeholders involved can take ownership of their selected objectives and approach. However, there is still a need to define the roles and responsibilities of stakeholders in the collaboration of stakeholder groups towards optimal leveraging (Hemmonsbey \& Tichaawa, 2018).

Despite the issue of stakeholder collaboration, the case study of sport event leveraging for Australia and the 2000 Olympic Games provides best practices of stakeholder collaboration pre- and post-event hosting. In an attempt to strategically position Australia as a leading destination for sport tourism, stakeholders representing both public and private institutions merged their efforts and objectives in pursuit of a greater goal. Stakeholders' leveraging efforts have moreover allowed this nation to capitalise the Olympic media around their brand image which essentially lead to stakeholders influencing respective journalist stories in respect to their destination brand.

In a different case where destination brand image was the impetus for strategic planning, Grix (2012) reported on Germany's attempts to engage in sport event leveraging to improve their nation's (poor) image abroad. This finding came as a result of international perceptions labelling the people as 'dominant', 'arrogant', and 'dull', as well as the Second World War and Nazi perceptions still remaining, especially in the British press (Grix \& Lacroix, 2006). These two examples thus contradict the earlier reference to Athens and their unsuccessful attempts to coordinate stakeholder efforts towards a joint strategic approach to leveraging the 2004 Olympic Games.

The discussion on strategic planning through sport event leveraging places a clear emphasis on the deliberate design and implementation of marketing strategies, the 
formulation of strategic objectives, as well as the establishment of stakeholder partnerships. From a practice perspective, case studies show that an engagement with global media networks in relation to the host destinations' image, product and service offering coherently positions tourism destination brands such that long-term positive perceptions are formed. Consequently, these strategic planning approaches are explored in the context of developing destinations by means of hosting annual, recurring events.

\section{THE RESEARCH STUDY}

The present study employed a qualitative research approach wherein in-depth faceto-face, semi-structured interviews were conducted with key industry stakeholders in sport, destination, and tourism branding organisations. Marshall and Rossman (2006) verify that a study focusing on the individuals' lived experience, much like the present study, typically relies on adopting an in-depth interview strategy. Key informants that participated in this study were purposefully selected by virtue of their experience and or background into the study scope and context. It was important to include a wide range of stakeholders representing both public- and private organisations within the spheres of national and local departments. More specifically, stakeholders in top management positions within national and local government representing the Department of National Tourism and the Department of Sport and Recreation were deemed critical as they support home-grown events and assist in setting strategic objectives as it applies to national and local imperatives. Moreover, directors and chief operators of private sport event companies involved in marketing and staging home-grown events were deemed critical for their role in applying leveraging strategies around the hosting of their events. Another group of stakeholders were key informants in the tourism operating industry due to their knowledge and insights into the tourists' experience during the hosting of sport events. The given sample of 24 is justified for the current study as, with qualitative research, the sample size in relation to interviews are based on the feasibility of the researcher as well as the level of saturation reached from the data collected.

Each interview was conducted at the workplace of the respondents and the interviews lasted approximately 45-60 minutes. The semi-structured interviews were guided by a set of questions relating to the topics identified through the literature review, although the interview protocol consisted of open-ended questions that allowed the interviewer to probe, or clarify, the issues raised, and to explore the particular areas of experience, or expertise, of the respondents involved. The interview questions largely focussed on the strategic planning of home-grown sport in relation to destination branding. In order to solicit stakeholder views on their understanding of strategic planning of home-grown events, specific questions on sport event leveraging in the context of home-grown events were posed. The interviews were digitally recorded and manually transcribed verbatim. Data was displayed, reduced and inductively coded by means of a software programme, Atlas. ti. Subsequent to developing the list of codes, themes were created and grouped which form the basis of the discussion section presented below. Ethical considerations were followed in that all the interviews were conducted with the prior consent of the respondents concerned. The respondents could at any time opt-out of the interview. Every effort was made to ensure the validity and reliability of the data, by means of constantly checking the interview transcripts, as well as continuously comparing them to the interview voice recordings and field notes made during the interview. To maintain anonymity, respondents are indicated by an ' $R$ ' and are assigned a number $(1,2,3 \ldots)$ which bear no relevance to their responses. Quotations are presented to illustrate practical examples or emphasise a common response. 


\section{Justification of South Africa as case study area}

As one of the most developed countries on the African continent, South Africa has provided a good example of a developing destination host of large-scale sport megaevents in the hope of promoting tourism and economic development. In previous years the country bid to host an array of sport mega-events, such as the 1995 Rugby World Cup, the 2003 Cricket World Cup, and the 2010 FIFA World Cup, all of which were capable of arousing global awareness, and of having an international impact. While the Olympic Games have yet to be hosted in South Africa, the unsuccessful Cape Town bid made for the 2004 Olympic Games, as well as the Durban bid made for the 2020 Games, has made South Africa a representative nation on the African continent for the hosting of the entire array of world spectacles Giampiccoli, Lee \& Nauright (2015).

South Africa further consistently host many successful recurring, small-scale sport events where the control over the organising, marketing and staging of such events are retained locally. For example, both Cape Town City and Durban have recognised that major annual events have become a trademark to their existing brand and that a substantial number of tourists have come to visit the city specifically for the purpose of attending, or of participating in, sport-related events (Turco et al., 2003; Maharaj et al., 2006; Hemmonsbey \& Knott, 2016). Despite such events having significantly gained increasing (national and international) participation, spectating and media coverage, Kotze (2006) argues that not enough is being done to strategically engage with such events for tourism promotion, internationally. Thus, in spite of their prominence in terms of home-grown event hosting, South Africa has yet to pursue brand positioning through sport event leveraging for the attainment of destination branding benefits. The current study, consequently, delves into assessing stakeholder strategies for leveraging small-scale sport events for destination branding purposes and addresses the gap in practice by providing recommendations for the leveraging of small-scale events within the developing South African context.

\section{RESULTS AND DISCUSSION}

Destination branding contextualised through the value proposition of sport

Respondents consistently described destination branding similar to the definition that is widely accepted in the literature; as a modern form of tourism promotion (Anholt, 2005; Boisen et al., 2018; Hanna \& Rowley, 2008). Respondents further alluded to the importance of destination branding strategies to create a distinctive brand identity as well as to establish brand positioning that will not only "attract captive markets" ( $\left.\mathrm{R}_{3}\right)$, but also "retain current tourism markets" (R3). These views are thus shared with the sentiments of Morgan et al. (2010), Greaves and Skinner (2010) and Filo et al. (2013) on the practices of strategic destination branding. Ways in which destinations can implement strategic marketing initiatives are set out by a key informant of sport event hosting in their description of destination branding;

I see destination branding as an opportunity to take the key elements and their strong points, whether it be natural beauty or its manmade beauty, and strategically market it so that people [tourists] will come and visit South Africa (R8).

Interestingly, in relation to the South African destination brand, respondents consistently agreed that, although South Africa has a clear global brand identity, individual South African cities still own their individual brand identities which might, at times, not reflect the overall nationwide brand. For example, (R1), (R2) and (R5) noted that coastal cities such as Cape Town and Durban typically share similar brands in terms of its natural 
setting as well as their sport event hosting as also supported by (Turco, et al., 2003; Maharaj et al., 2006; Hemmonsbey \& Knott, 2016), whereas other inland cities such as Johannesburg and Tshwane are commonly viewed as a "business hub with a corporate brand identity" ( $\left.\mathrm{R}_{5}\right)$. Due to such views, the destination brand identity of South Africa is usually perceived as a 'diverse place brand' (R8). In light of such findings, Kapferer (2012) argues that destinations need to establish a value proposition that is promised to be delivered to visitors of a destination. This study's findings, together with findings of other empirical studies such as Govers and Go (2009) and Zhang and Zhao (2009) show that sport events are significantly considered as an ideal value proposition for strategic brand positioning. However, as such studies refer to the sport mega-event, it usually isolates such events as the sole proposition in relation to the destinations' marketing arms. Whereas the current study zooms in to home-grown events, discussions from respondents reveal the interrelated of home-grown sport together with other tourism products and services, such as the natural setting and destination attractions, and viewed that, although it is important to establish a niche sport market "as people consistently travel for sport" (R4), a shared value proposition that appeals to both sport and leisure tourism markets are important to stimulate tourism in the long-haul. In reference to the strategic planning of home-grown sport events for destination branding, while illustrating value propositions of Cape Town, South Africa's brand, a key informant national department of tourism posited that;

It (i.e. destination branding) is like a demonstration of the product. You have these great images of the country, but you only see and experience it when someone is participating in an event in a particular destination, showcasing the destination images like Table Mountain, or swimming across the ocean to Robben Island in Cape Town. So, that is what needs to happen, the leveraging of sport [with other tourism products] (R8).

For such reasons mentioned above, home-grown events should then be strategically planned to incorporate cross-leveraging and marketing activities with other tourism amenities and attractions to ensure not only a consistent brand message for South Africa across a variety of tourism niche markets, but also to encourage equal economic impacts for the host destination long after the event has passed. While such perceptions exist, there was no mention of the practical application of such strategic marketing plans for South Africa.

Opportunities for strategic planning through home-grown sport events

Due to the incipient concept of home-grown events in the literature, respondents were asked about their understanding of this concept. Hemmonsbey and Tichaawa (2019: 259) present a list of major events in South Africa which encompass a variety of sporting disciplines, from cycle tours, marathon events, golf events, water sport and multi-disciplined events including triathlons. While some of the respondents of the present study were not overly familiar with the home-grown concept, other responses typically exemplified an understanding of home-grown events in view of the aforementioned major events. Notwithstanding the relative confusion about the 'home-grown' concept, (R1), (R3), (R5), (R11) and (R12) consistently described home-grown events according to their "iconic" status, which ties in with the interpretation of Getz, Svensson, Peterssen \& Gunnervall. (2012) on the 'hallmark' and 'sport mega-event' concepts. However, in contrast to the megaevent, the home-grown event is seen to be conceptualised, initiated and organised locally with an opportunity to grow internationally and moreover has the 'ability to contribute to some kind of destination branding' (R1) from beyond the national borders concerned. A response that demonstrates an iconic home-grown sport events in Cape Town reads as follows; 
[The] Two Oceans Marathon event was started locally in 1977/78, and [it] has become an iconic event, which has grown internationally. Similarly, the Cape Town Cycle Tour, formally known as the Pick n Pay Argus [i.e. Cape Argus Pick n Pay] Cycle Tour, that is also home-grown. Now, it is 38 ooo timed cyclers, from [i.e. with] both domestic and international participation (R1).

From these views on home-grown events, respondents believed that it is imperative for the city and nation to capitalise on such events for tourism and destination branding benefits through strategic planning of home-grown sport. Typical opportunities for leveraging in the literature in which respondents agreed upon usually include the huge following of event visitors (participants and spectators), as well as the trade and media that follows an event (Chalip, 2004). However, the current study argues for additional opportunities linked to trade and exhibitions that present new business for the destination. Respondents consistently recognised the "value of trade exhibitions and conventions in its return on investments" (R8), thus should be planned and leveraged accordingly. From a practical perspective, a key informant in events planning recognised the value of other sport- or non-sport-related business opportunities, various South African provinces have set up conventions and events bureaus for supporting both sport and business conventions. For example;

Gauteng tourism has set up a Gauteng Conventions and Events Bureau. So has [i.e. have] a few other provinces ... South African Tourism now has the National Conventions and Events Bureau. The focus of these Bureaus are [i.e. is] not only on conventions and exhibitions but it [i.e. they] also supports [i.e. support] sport and cultural events. They have now realised the need for this type of entity that is going to support events (R3).

By adding conventions, exhibitions, sport, and cultural events to the list of attractions on the events calendar, South Africa could competitively position its brand amongst other leading global conference and convention hosts, such as Australia, which has successfully achieved brand positioning as a result of its sport event leveraging (Chalip, 2002). Moreover, from an event media perspective, respondents agreed that "media plays a significant role in enhancing the image of South Africa around sport events" (R12). However, it is argued by some key informants that the media (both mainstream and social media) can be used more effectively to convey more authentic brand messages of South Africa instead of the dominant messages of crime and socially unsettled issues currently plaguing the country. While such negative media perceptions have not necessarily impacted on visitation numbers for avid sport event fans, as is espoused by Tichaawa and Bob (2015), (R8) emphasised that strategic media partnerships are important for conveying positive messages of the destination and made the following practical recommendation towards this strategic planning:

There are opportunities to establish relationships with media houses and journalists around events, to deliberately brand the event and South Africa as a destination. When there is an event, we would take care of travelling sports journalists. We will entertain them; we will show them what South Africa is all about. We have a hosting programme as well, where we host journalists from around the world, so it's how do you align the hosting of sports journalists to get positive messages across (R8).

While strategic partnerships with event media are encouraged, respondents similarly believe in the benefits of establishing partnerships between the local, national 
and provincial government, tourism departments and respective sport event organisers and commercial sport brand sponsor in order to facilitate the strategic planning of all facets of the destination branding through home-grown sport. However, the disconnected strategic objectives and mandates of individual stakeholders in government- that speaks towards the social imperatives of the destination- and private businesses-that are usually linked to profit- mostly implicate strategic planning of effective stakeholders' collaborative efforts. Thus it is reiterated by Hemmonsbey and Tichaawa, (2018) that the fostering of stakeholder collaboration has become a clear imperative in addition to the strategic objectives as mentioned in the general event leveraging framework by Chalip (2004). Due to the significant finding on stakeholder collaboration and varied objectives, these results underpin previous studies conducted on strategic planning by Cooper (1995) and Bramwell (1997) as well as in recent leveraging research by O'Brien and Chalip (2008) and Smith (2014) and the findings of Hemmonsbey and Tichaawa (2018) which, when all things considered, threatens the trajectory of strategic planning through the use of sport and in particular home-grown events.

\section{process}

The importance of stakeholder engagement in the strategic planning

Despite the need to refine stakeholders' collaborative efforts, when approaching strategic planning through leveraging activities, respondents believed that there are key duties that stakeholders need to fulfill. From policy perspective, the municipal or local government is believed to act as the sponsor of home-grown events. Sponsorship may take various forms, for example, cash or in-kind rewards in terms of "providing medical and traffic services, [as well as] making sure that the event runs smoothly" (R5). From a destination branding perspectives, local destination marketing organisations "invest in tourism destination marketing and also the marketing of the city as a brand, through our marketing agencies and marketing events" (R6). Similarly, the role of the actual event is to ensure that "the event is a success" and that "we [the event] reaches its financial and social targets" (R4). While local government has, however, establish their clear roles in terms of event sponsorship, home-grown events provide the platform strategic planning through stakeholder engagement where this particular group of stakeholder can now extend their contribution towards strategic marketing initiatives in tandem with destination marketing organisations and commercial sport brand sponsors of a particular event. As such, the responsibility of strategic branding and sport event leveraging is alleviated from one group of stakeholders to a variety of different stakeholder groups, which further creates symbiotic stakeholder relationships across the entire range of stakeholders in sport and tourism.

Examples of such strategies not only emanate in the co-branding strategies of the local and provincial government in their strategic visions to position events at the forefront of the destination brand but also in the national imperative to stimulate tourism through both corporate and sporting events. An example of co-branding is provided by a key informant in local government as a result of their strategic planning;

Cash is only one way, in terms of the brand, [that] we invest in tourism destination marketing and also the marketing of the city as a brand, through our marketing agencies and marketing events. We [the city] have the slogan, and we push that into our city's events. Therefore, marketing, co-marketing, co-branding, television rights, and sharing in the income stream of that, make our leveraging possible (R6).

In relation to the destination brand image, strategic planning through co-branding initiatives proved to be consistent across the views of respondents. For example, a wide- 
range of respondents believed that it is important to establish a direct association of event and host city brand. In that way, event visitors inherently associate the destination with sport and vice versa. This type of strategic initiative is arguably not otherwise possible with destinations paring their brand image with sport mega-events events with a once-off nature does not provide regular opportunities for brand image association. Such views are emphasised by a key informant in local government in that;

We [the city] have pushed ourselves to say that we are going to brand events. So, you will always get that 'Cape Town' or 'Western Cape' name attached to the event for [purposes of] familiarity and awareness. For example, the Cape Town Cycle Tour [and the] Cape Town Marathon. (R1).

Such performance of co-branding supports research, in terms of the important role played by stakeholders within the sport tourism domain, according to which the stakeholders are seen to pool resources in the strategic planning and management of sport tourism events (Tichaawa et al., 2018).

\section{IMPLICATIONS AND CONCLUSION}

The present study purposed to determine the views of stakeholders on tactics that form part of strategic planning around home-grown events which stimulate and promote tourism and destination branding benefits for the host destination. The leveraging theory essentially recognises events as opportunities for strategic planning, however such theory is typically informed from the perspective of developed destination contexts (Chalip, 2004). On the basis of the results and discussions, strategic planning is greatly advocated for destination branding benefits in terms of tourism and economic development which is congruent with the benefits presented within the widespread theoretical notion on leveraging. However, from a developing destination perspective, strategic planning of events is further encouraged to augment and to, more importantly, contribute to unique elements of the destination brand, such as, global brand positioning; social imperatives in health and education; trade and exhibitions; and international media perceptions, thus extending the leveraging theory to include unique brand related elements for strategic consideration when approaching sport event planning and hosting. A further contribution to the destination branding theory is made by investigating a developing, African brand with unique brand attributes and offerings which are frequently neglected in the extant destination branding literature.

One implication related to stakeholder practice and policies is linked to the alignment of strategic objectives for leveraging between event industry stakeholders and those stakeholders in local and national government, especially within the tourism and destination branding departments. The lack of strategic alignment in stakeholder objectives implicitly impede stakeholder collaboration efforts and strategic partnering especially pre, and post event hosting, despite their efforts to pool resources during the event hosting stage. International best practices demonstrate opportunities for stakeholder collaborations and highlight the efficacy of strategic partnerships and the integration of strategic objectives into the policies of a range of stakeholders within public and private entities, media and other tourism operatives during all stages of event hosting (Chalip, 2000; Grix 2012). Despite the consistent debate on stakeholder collaborative efforts and varied stakeholder objectives, the South African destination brand has realised the value of trade exhibitions and conventions in its return on investments from event support and has consequently been leveraging them towards achieving tourism benefits. The establishment of Conventions and Events Bureaus within various municipalities 
implies that the need for this type of entity to support events has been recognised. To this end, the results reveal a clear strategic initiative in the form of strategic partnerships, beyond those opportunities mentioned in the leveraging theory related to international perspectives. Therefore, to achieve realised benefits from sport event hosting, serious attention should be given to policy development where industry and government objectives align and where event planning and hosting are approached more strategically by being inclusive to other tourism and economic opportunities.

More specific to sport events, while the literature provides significant evidence of the use of mega-events for strategic planning, the results and discussions of this paper reveal the significant contribution of home-grown sport events to establishing value propositions for destination brand positioning. Compared to the mega-events that can be regarded as a stand-alone value proposition due to the global nature and unique hosting, home-grown events are encouraged to accompany other tourism amenities, such as the destination's natural attractions and tourism offerings, to particularly attract repeat visits and encourage longer visitor stays post-event hosting. What further sets home-grown events apart from the mega-events is not only the recurring nature in event hosting which results in an annual reach and frequency of sport tourists to a destination but also the ability to engage in strategic co-branding initiatives where destination stakeholders merge their brand identities to form associations in the minds of their target audience.

For example, the Cape Town Cycle Tour event allows government and event organisers together with their commercial sport brand sponsors to leverage the event through its name brand identity. This causes Cape Town to be viewed as a global brand and therefore attracting global audiences to a local event. Such strategic marketing initiatives, therefore, distinguish the destination brand image while engaging stakeholders in both public and private institutions/environments/industries. Despite the view that collaboration between key stakeholders appear elusive, such strategic initiatives present a start to strategic stakeholder partnerships. For the broader South African destination brand however, strategies to incorporate such marketing initiatives are not essentially implemented despite being realised across stakeholder perceptions. While a dialogue of strategic planning in the context of home-grown sport events is introduced, this study acknowledges that critical analysis into a specific home-grown event case might deepen the understanding of stakeholder collaboration and provide justifications into their decisions to secure strategic partnerships. This could be of relevance to stakeholder confidence at both local and national levels to commit to sport event leveraging initiatives through home-grown events. This study presents unique insights into the developing destination context in relation to sport event hosting and strategic planning through leveraging activities which has been extensively overlooked in the known destination branding and sport event leveraging theory. Therefore it makes a significant and unique contribution to the extant destination branding and event leveraging discourse. While the dialogue of home-grown events has started, this concept could be further explored in relation to its influence on other destination amenities such as trade industries.

\section{Acknowledgments}

This paper is developed based on a doctoral thesis submitted to the University of Johannesburg, by the same authors.

\section{REFERENCES}

Anholt, S. (2005). Some important distinctions in place branding. Place Branding, 1(2):116-121.

Baker, B. (2012). Destination branding for small cities. 2nd edition. Portland, OR: Creative Leap Books. 
Balakrishnan, M. S. (2009). Strategic branding of destinations: A framework. European Journal of Marketing, 43(5/6):611-629.

Boisen, M., Terlouw, K., Groote, P. \& Couwenberg, O. (2018). Reframing place promotion, place marketing, and place branding - moving beyond conceptual confusion. Cities, 80:4-11.

Bramwell, B. (1997). Strategic planning before and after a mega-event. Tourism Management, 18(3): 167-176.

Brown, G., Chalip, L., Jago, L. \& Mules, T. (2004). Developing brand Australia: Examining the role of events. In Destination branding: Creating the unique destination proposition: 279-306. Edited by Morgan, N., Pritchard, A. \& Pride, R. 2nd edition. Oxford: Elsevier.

Camilleri, M. A. (2018). Strategic perspectives in destination marketing. London. IGI Global.

Chalip, L. (2002). Using the Olympics to optimise tourism benefits: University lecture on the Olympics. Barcelona: Centre d'Estudis Olímpics (UAB). Available from: http://olympicstudies.uab.es/lectures/web/pdf/chalip.pdf

Chalip, L. (2004). Beyond impact: A general model for host community event leverage. In Sport tourism: Interrelationships, impacts and issues: 226-252. Edited by Ritchie, B. W. \& Adair, D. London: Channel View.

Chen, N. \& Funk, D. C. (2010). Exploring destination image, experience and revisit intention: A comparison of sport and non-sport tourist perceptions. Journal of Sport \& Tourism, 15(3):239-259.

Chen, S. \& Misener, L. (2019). Event leverage in a non-host region: challenges and opportunities'. Journal of Sport Management, (oo): 1-14.

Cooper, C. (1995). Strategic planning for sustainable tourism: the case of the offshore islands of the UK. Journal of Sustainable Tourism, 3(4):191-209.

Cornelissen, S., Bob, U. \& Swart, K. (2011). Towards redefining the concept of legacy in relation to sport megaevents: Insights from the 2010 FIFA World Cup. Development Southern Africa, 28(3):307-318.

Filo, K., Chen, N., King, C. \& Funk, D. C. (2013). Sport tourists' involvement with a destination: A stage-based examination. Journal of Hospitality \& Tourism Research, 37(1):100-124.

Getz, D., Svensson, B., Peterssen, R. \& Gunnervall, A. (2012). Hallmark events: Definition and planning process. International Journal of Event Management Research, 7(1/2):47-67.

Giampiccoli, A., Lee, S. \& Nauright, J. (2015). Destination South Africa: Comparing global sports mega-events and recurring localised sports events in South Africa for tourism and economic development. Current Issues in Tourism, 18(3):229-248.

Govers, R. \& Go, F. (2009). Place branding: Glocal, virtual and physical identities, constructed, imagined and experienced. Basingstoke: Palgrave Macmillan.

Greaves, N., \& Skinner, H. (2010). The importance of destination image analysis to UK rural tourism. Marketing Intelligence \& Planning, 28(4): 486-507.

Grix, J. \& Lacroix, C. (2006). Constructing Germany's image in the British press: An empirical analysis of stereotypical reporting on Germany. Journal of Contemporary European Studies, 14(3):373-392.

Grix, J. (2012). 'Image' leveraging and sport mega-events: Germany and the 2006 FIFA World Cup. Journal of Sport and Tourism, 17(4):289-312.

Hanna, S. \& Rowley, J. (2008). An analysis of terminology use in place branding. Journal of Place Branding and Public Diplomacy, 4(1):61-75.

Hemmonsbey, J. \& Knott, B. (2016). Branding an African city through sport: The role of stakeholder engagement. African Journal of Hospitality, Tourism and Leisure, 5(3):1-14.

Hemmonsbey, J., \& Tichaawa, T.M. (2019). Using non-mega events for destination branding: a stakeholder perspective. GeoJournal of Tourism and Geosites, 24(1): 252-266.

Hemmonsbey, J., Tichaawa, T. \& Knott, B. (2018). Conceptual framework for strategic destination branding through leveraging home-grown sport events. South African Journal for Research in Sport, Physical Education and Recreation, 40(2):81-98.

Horne, J. \& Manzenreiter, W. (2006). An introduction to the sociology of sports mega-events. Sociological Review, 54 (Supplement 2):1-24.

International Olympic Committee. (2009). Beijing facts and figures report, August 2009 Update. Available from https://www.olympic.org/olympic-legacy/ /media/A8264DD681D34B459Bo26CBD6FFD4D78.ashx

Jago, L., Dwyer, L., Lipman, G., Van Lill, D. \& Voster, S. (2010). Optimising the potential of mega-events: An overview. International Journal of Event and Festival Management, 1(3):220-237.

Kapferer, J. N. (2012). The new strategic brand management: Advanced insights and strategic thinking. $5^{\text {th }}$ edition. London: Kogan Page.

Karadakis, K. \& Kaplanidou, K. (2012). Legacy perceptions among host and non-host Olympic Games residents: A longitudinal study of the 2010 Vancouver Olympic Games. European Sport Management Quarterly, 12(3):243-264.

Kim, W., Jun, H., Walker, M. \& Drane, D. (2015). Evaluating the perceived social impacts of hosting large-scale sport tourism events: Scale development and validation. Tourism Management, 48:21-32.

Knott, B., Fyall, A. \& Jones, I. (2017). Sport mega-events and nation branding: Unique characteristics of the 2010 FIFA World Cup, South Africa. International Journal of Contemporary Hospitality Management, 29(3):900-923.

Kotze, N. (2006). Cape Town and the Two Oceans Marathon: The impact of sport tourism. Urban Forum, 17(3):282-293. 
Lui, D. (2016). Social impacts of major sports events perceived by host community. International Journal of Sport Marketing and Sponsorship, 17(1):78-91.

Maharaj, B., Sucheran, R. \& Pillay, V. (2006). Durban - A tourism mecca? Challenges of the post-Apartheid era. Urban Forum, 17(3):262-281.

Marshall, C. \& Rossman, G. (2006). Designing qualitative research. Thousand Oaks, CA: SAGE.

Morgan, N. J., Pritchard, A. \& Pride, R. (2010). Destination branding: Creating the unique destination proposition. 2nd revised edition. Oxford: Elsevier.

Nauright, J. (2013). Selling nations to the world through sports: Mega-events and nation branding as a global diplomacy. Public Diplomacy Magazine, (9):22-27.

O'Brien, D. \& Chalip, L. (2008). Sport events and strategic leveraging: Pushing towards the triple bottom line. In Tourism management: Analysis, behaviour and strategy: 318-338. Edited by Woodside, A. G. \& Martin, D. Washington, DC: CABI.

Pike, S. D. (2009). Destination brand positions of a competitive set of near-home destinations. Tourism Management, 30(6):857-866.

Ritchie, J. R. \& Ritchie, R. J. B. (1998). The branding of tourism destinations: Past achievements and future challenges. A basic report prepared for presentation to the 1998 Annual Congress of the International Association of Scientific Experts in Tourism Marrakech, Morocco, September 1998.

Smith, A. (2014). Leveraging sport mega-events: New model or convenient justification? Journal of Policy Research in Tourism, Leisure and Events, 6(1):15-30.

Swart, K. \& Bob, U. (2012). Mega sport event legacies and the 2010 FIFA World Cup. African Journal for Physical, Health Education, Recreation and Dance, September (Supplement 1):1-11.

Swart, K., Tichaawa, T., Othy, J. D. O. \& Daniels, T. (2018). Stakeholder perspectives of sport tourism development in Gabon: A case study of the Africa Cup of Nations. EuroEconomica, 1(37):177-189.

Tichaawa, T. M. \& Bob, U. (2015). Leveraging mega-events beyond the host nation: A case study of the 2010 FIFA World Cup African Legacy Programme in Cameroon and Nigeria. Leisure Studies, 34(6):742-757.

Turco, D. M., Swart, K., Bob, U. \& Moodley, V. (2003). Socio-economic impacts of sport tourism in Durban Unicity, South Africa. Journal of Sport Tourism, 8(4):223-239.

Weed, M. (2009). Progress in sports tourism research? A meta-review and exploration of futures. Tourism Management, 30(5):615-628.

Zhang, L. \& Zhao, S. X. (2009). City branding and the Olympic effect: A case study of Beijing. Cities, 26(5):245-254.

Ziakas, V. \& Boukas, N. (2014). Post event leverage and Olympic Legacy: A strategic framework for the development of sport and cultural tourism in post-Olympic Athens. Journal of Sport, 1(2):87-102.

Ziakas, V. \& Costa, C. A. (2011). The use of an event portfolio in regional community and tourism development: Creating synergy between sport and cultural events. Journal of Sport and Tourism, 16(2):149-175.

Ziakas, V. (2018). Integrating sport events into destination development: A tourism leveraging event portfolio model. In EURAM Annual Conference 2018, 19-22 June 2018, University of Iceland, Reyjavic.

Submitted:

16.07.2019
Revised:

23.09.2019
Accepted and published online 25.09.2019 